\title{
Structural Asymmetries and Peace: Hope or Despair?
}

\author{
Cheryl de la Rey \\ Department of Psychology \\ University of Cape Town
}

\begin{abstract}
This article suggests that where one is positioned in the current geopolitical system is likely to have an influence on whether one feels hope or despair. In this respect material asymmetry as a divisive influence is noted and it is argued that poverty reduction is a crucial component in defining a culture of peace. The need for sharing of resources as envisioned in the definition offered by Boulding is endorsed. Although the reduction of material asymmetry is seen as crucial, it is however, not seen as sufficient for the attainment of a peace culture. Redressing other power differentials such as gender is also viewed as crucial. The insights offered by Elise Boulding on the role of nongovernmental organizations are highlighted but the need to examine civil society more widely is also noted. In particular, the question of the meaning of citizenship is emphasized. In conclusion, the importance of developing a holistic, interdisciplinary approach that draws on cooperation and interdependence is affirmed and it is argued that there is sufficient reason for hope.
\end{abstract}

"The century started off so promisingly" proffers Elise Boulding at the very outset of a highly thought-provoking article. "For whom?" I wondered in response. Did the century start off promisingly from the point of view of many of those at the southern tip of Africa? In South Africa the turn of the century was marked by the Anglo-Boer War, a power struggle amongst a White minority to determine authority and control over a region with a Black majority population who did not enjoy rights of citizenship. With many people in concentration camps and labour service, I wonder whether there was a general feeling of promise. I raise these questions not to produce answers, but to draw attention to the relevance of positionality. 


\section{THE RELEVANCE OF POSITIONALITY}

Where one is positioned in the global geopolitical system matters-it may determine whether one sees a problem or not and, if so, how the problem is defined and then, the solutions that are offered in response. Contemporary global geopolitics is shaped by inequalities at multiple levels and as Elise Boulding points out, some disparities seem to be increasing unchecked to the extent that "The rich grow richer, the poor grow poorer" (p. 198). Stark inequalities differentiate rich and poor, powerful and powerless. As we face the turn of another century, some people may feel hope and others may feel despair, depending on where they are positioned in relation to the disparities that divide human communities across the globe.

\section{MATERIAL ASYMMETRY}

Material asymmetry divides the nations of the world. Countries in Africa, South America, and Asia bear the burden of huge external debts and staggering levels of poverty. Economic inequities however, do not only divide north and south, industrialized and developing nations; material disparities also divide people within nations. Schwebel (1997), for example, drew attention to how people in the United States are divided by differential access to employment and job security. In pointing to the role of long-term unemployment, job insecurity, and underemployment in producing forms of contemporary violence, Schwebel was of course building on the work of Galtung (1996), who examined how inequities in economic systems constitute a form of structural violence that underlies the varied forms of violence and conflict that confront us as we enter the next century.

Poverty reduction is therefore a necessary and vital element in the work of those who seek to bring about peace in the world. Indeed, it is a crucial component of Elise Boulding's working definition of peace culture. Sharing resources is integral to her definition. Rightly so, as the sharing of resources is a challenge that confronts us all at several levels. First, at the global level there are several pressing issues around foreign aid, the cancellation of debt, and equitable trade. Second, at the regional level there are a number of agreements that attempt to reduce disparities through economic and political cooperation. In southern Africa the agreements and ongoing dialogue among the countries that form the Southern Africa Development Community are examples. Third, at the national level the challenge to achieve a more equitable distribution of wealth among citizens is an issue for nearly all countries, from those among the wealthiest such as the United States (as pointed out by Schwebel, 1997), to those countries that rank among the poorest. It is the most pressing challenge for South Africa, my native country. Job creation, the provision of housing, education, and health and social services to the poor are among the key issues to be dealt with by South Africa's second democratically elected government as this century gives way for the next. 


\section{POWER DIFFERENTIALS}

But, even though redressing material inequalities is fundamental to the creation of a peace culture, it is not sufficient for, as many cases show, economic asymmetries are often inextricably interwoven into other systems of powerlessness and oppression. The absence of power differentials is therefore a necessary and important component of Elise Boulding's working definition of a peace culture. Again, she rightly points out that a culture of peace involves nurturant living and this cannot occur where there are structured power differentials.

\section{Gender}

Gender as a locus of power difference is often not given sufficient attention in our analyses of major social issues. Gender-based violence such as rape, sexual harassment, and domestic abuse is one of the most widespread forms of violence that occur during times of war, in the aftermath, and during times when there is no ostensible warfare. It is a pervasive form of violence. I believe that given the enormity of the problem more space may have been given to a more probing analysis of gender in the article. Gender is alluded to, but not in sufficient depth.

One of the gender-related ideas is that women have a special role in bringing about social transformation. Is this justified, I wonder? Although there is evidence that women are less likely than men to initiate and perpetrate violence, there is also evidence that women are just as likely as men to uphold, perpetuate, and collude in systems of oppression. Moreover, given that women as a group are underrepresented in governments and other institutions that wield power and authority, our potential to have an impact is likely to be rather limited at the global, regional, and national levels unless we form strong coalitions and mass-based movements. On this specific note, the article suggests that there is hope as civil society is flourishing as never before. In support of this the growing number of nongovernmental organizations (NGOs) across the world is noted.

\section{THE ROLE OF NGOS}

With reference to the role of NGOs, Elise Boulding offers several insightful comments. The positive contribution made by NGOs in raising awareness around key issues, in challenging dominant views and ways of knowing and in developing knowledge that is useful in working toward cultures of peace is foregrounded, yet constructive critique of NGOs is also offered. The article points to their tendency toward parochialism, territorialism, and sometimes insensitivity toward local, contextual needs. Nonetheless, there is no doubt that NGOs are important and perhaps 
this is especially so with regard to gender issues. In South Africa the struggle for gender equality is currently most visible within the domain of NGOs that undertake activities such as lobbying, advocacy, education, and the provision of services such as counseling.

NGOs are undoubtedly an important presence in civil society. However, any tendency to simply equate civil society with the existence of NGOs must be avoided. There are numerous areas and individuals outside of the reach of NGOs; in many contexts these are likely to be individuals living in poor, rural areas at the margins of the structures and processes of organized civil society and government. What is the experience of civil society for such people?

\section{THE MEANING OF CITIZENSHIP}

Confronting the question of the meaning of citizenship is crucial to the building of peaceful societies. What we have learned from history is that the exclusion of people from citizenship leads to violence. For the majority of South Africans citizenship only became a lived reality in this last decade of the 20th century. Therefore, for us it is a precious and contested concept. The first experience of citizenship for most South Africans was lived through the act of voting in 1994. Six years later after having voted for the second time, there is an awareness that citizenship involves more than the act of voting; it includes participation and representation in the institutions of society. But, a pressing question yet to be dealt with satisfactorily, is how to ensure equal participation, representation, and rights for people who differ from one another in many respects - ethnicity, religion, gender, and culture are but a few of the sites of difference. Too frequently equality of citizenship is interpreted as sameness with the effect of disrespecting difference. The attainability of global peace depends on our ability to find workable solutions to these and other questions.

Developing the meaning of citizenship, finding ways to minimize asymmetries, and overcome structural violence fits in well with the general shift in peace-related work away from a narrow focus on violence and its consequences toward a greater focus on prevention and sustainability. It is vitally important that we continually examine the past to uncover the lessons to be learned from history so that we can prevent the mistakes of the past. In so doing we have to be careful not to overly focus on the conflicts of the past, but to also examine, as Elise Boulding does, the lessons to be learned from the places and times when peace has been enjoyed.

\section{A Holistic Approach}

To derive maximum gain from scrutinizing the past as well as probing new questions and challenges, we need a holistic interdisciplinary approach and the kind of 
collaborative reflection envisioned in the article. As pointed out, we lose numerous opportunities for developing new knowledge through duplication, turfism, and competitive efforts rather than collaboration and interdependence. Nevertheless, there is sufficient reason for hope-this is to be seen in the various millennialist peace efforts in the NGO sector as described in the article. But perhaps the greatest source of hope is to be found in a lesson gleaned from history, namely that change is inevitable and that movements to end oppression, violence, and war can bring about immense positive changes. In recent history South Africa is a case in point.

\section{REFERENCES}

Galtung, J. (1996). Peace by peaceful means. London: Sage.

Schwebel, M. (1997). Job insecurity as structural violence: Implications for destructive intergroup conflict. Peace and Conflict: Journal of Peace Psychology, 3(4), 333-351. 
Injustice, oppression, fraud, lying, whatever acts would be crimes, whatever habits would be vices if manifested in the pursuit of individual interests, when manifested in pursuit of national interests become sublimated into virtue.

Jeremy Bentham, 1789 